\title{
Chronic glomerular nephritis in a man with an IgM cold autoantibody of anti-I specificity and a cold lymphocytotoxic antibody
}

\author{
R. R. BAIley, M. El-MAghraby, I. C. BALFOUR, AND T. R. MitChELL \\ From the Departments of Medicine, Haematology, and Experimental Pathology, Charing Cross Hospital \\ Medical School, Fulham and West London Hospitals, London
}

SYNOPSIS This communication describes a young man with chronic glomerular nephritis whose serum contained cold antibodies directed against both red cells and lymphocytes. A renal biopsy revealed unusual histological features including extensive deposits of IgM and complement. Although abnormal immune responses are not uncommon in chronic renal failure, it is suggested that there may be a causal relationship between the underlying renal lesion and the abnormal antibodies.

The aetiological processes involved in the majority of patients with chronic glomerular nephritis are unknown.

The case reported here is that of a young man where it is possible that the glomerular injury was secondary to circulating atypical cold antibodies with or without the agency of complement.

\section{Case History}

R.R., a 24-year-old Ceylonese engineering student, was known to have had proteinuria and intermittent ankle oedema for nine years. He had been treated with short courses of corticosteroids and more recently with hypotensive therapy for mild hypertension. For the past four years he had noted polyuria and nocturia with increased thirst. At the time of admission to this hospital his major complaint was of a painful flitting arthralgia of most of the small joints, particularly of the hands, wrists, and elbows. He was also suffering severe muscle cramps.

On examination he was an intelligent, healthy looking man with moderate pallor. He was mildly hypertensive. A trace of ankle oedema but no sacral oedema was noted. The liver was not palpable but the spleen was firm, tender and palpable 3 fingerbreadths below the costal margin.

\section{INVESTIGATIONS}

At presentation the haemoglobin was $9.1 \mathrm{~g} / 100 \mathrm{ml}$, PCV $27.5 \%$, WBC $4800 / \mathrm{cmm}$, reticulocytes $2 \%$, Received for publication 21 October 1971. platelet count $75000 / \mathrm{cmm}$, and ESR $91 \mathrm{~mm} / \mathrm{hr}$. The red cells showed moderate anisocytosis and occasional burr cells. The bone marrow aspirate was normal. Coagulation studies, haemoglobin electrophoresis, G6PD assay, and osmotic fragility were normal. Red cell survival using ${ }^{51}$. chromium was 21-25 days (predicted 25-32 days). LE cells were not detected. Abnormal biochemical results included blood urea $106 \mathrm{mg} / 100 \mathrm{ml}$, serum bicarbonate 16 m-equiv/l, serum albumin $2.5 \mathrm{mg} / 100 \mathrm{ml}$, serum creatinine $6.5 \mathrm{mg} / 100 \mathrm{ml}$, and a mean daily creatinine clearance of $15 \mathrm{ml} / \mathrm{minute}$. The excretion of protein varied between 17 and $30 \mathrm{~g}$.

The serum immunoglobulin profile was as follows: IgG $590 \mathrm{mg} / 100 \mathrm{ml}$ (normal 500-1600), IgA $150 \mathrm{mg} / 100 \mathrm{ml}$ (normal 125-425), and serum IgM $55 \mathrm{mg} / 100 \mathrm{ml}$ (normal 47-170). The serum complement $(\beta \mathrm{IC}+\beta \mathrm{IA})$ measured $45 \mathrm{mg} / 100 \mathrm{ml}$.

Urine specimens were negative for urobilinogen, bile, and haemosiderin.

RENAL BIOPSY

Two fragments of kidney obtained by the percutaneous technique revealed an end-stage glomerular nephritis. Paraffin sections contained no normal glomeruli. All were virtually obliterated by an eosinophilous material which contained some collagen but no material reacting as for fibrinoid (MSB technique-Lendrum, Fraser, Slidders, and Henderson, 1962). The deposits reacted strongly with Congo Red and Thioflavine $\mathbf{T}$ but were not birefringent. A variable degree of capsular fibrosis 
was present in all glomeruli. A diffuse interstitial fibrosis was evident with large aggregates of lymphocytes and plasma cells. Tubular atrophy was marked. Some arterioles showed fibroelastic intimal hyperplasia; there was a chronic hyaline change (blue with MSB) in the media of others (Fig. 1). In the normal part of the glomeruli the basement membrane was normal (methanamine silver stain). Elsewhere the basement membrane was condensed and frayed with an even granular pattern. The normal pattern of the basement membrane was distorted by the eosinophilous material stained with haematoxylin and eosin and the red material stained with Congo Red. Cryostat sections contained only three glomeruli. IgG was present in a diffuse granular fashion in all these glomeruli (Fig. 2). IgA was present in a similar distribution. In one glomerulus beta IC deposits were distributed in an irregular globular pattern, the largest deposit being intensely reacting and about $50 \mu$ in diameter (Fig. 4). Similar intensely reacting deposits of IgM were present in the same glomerulus with an associated reaction around what appear to be capillary walls (Fig. 3). No linear deposition of antibody or complement was noted. IgG, IgA, and beta IC were present in many of the interstitial cells.

\section{RED CELL SEROLOGY}

The patient's cells gave a positive direct Coombs test (DCT) at a titre of $1: 32$. With specific anti-beta IC globulin it was positive but negative with specific anti-IgG.

The patient's serum contained a cold autoantibody with both $I$ and i specificity. The reactions

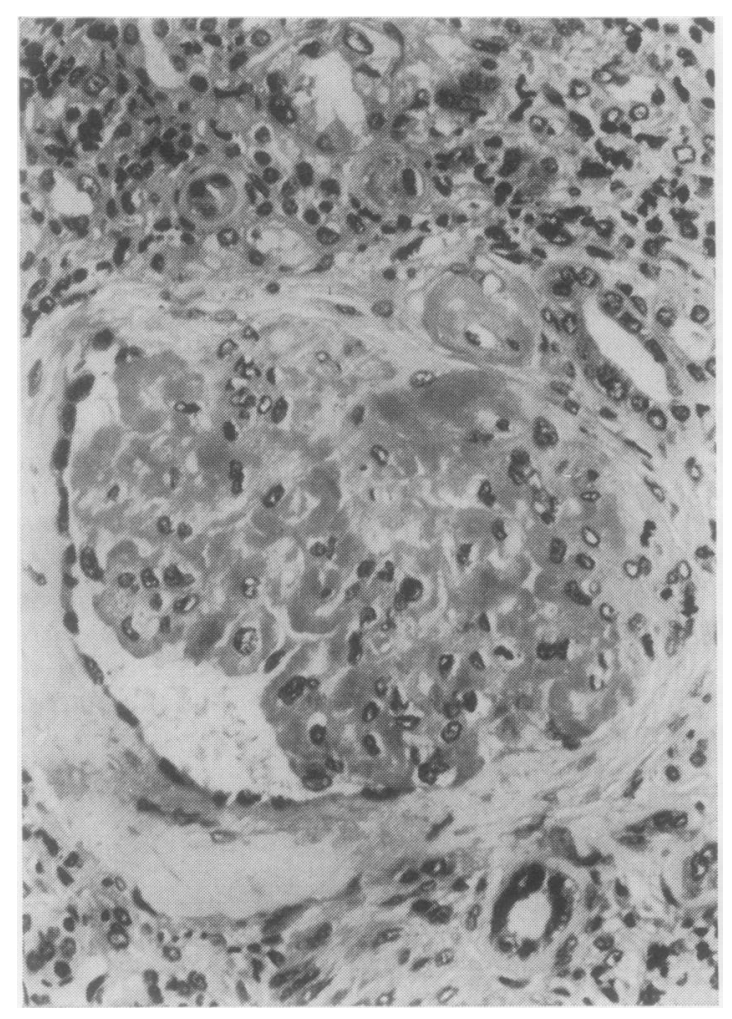

Fig. 1.

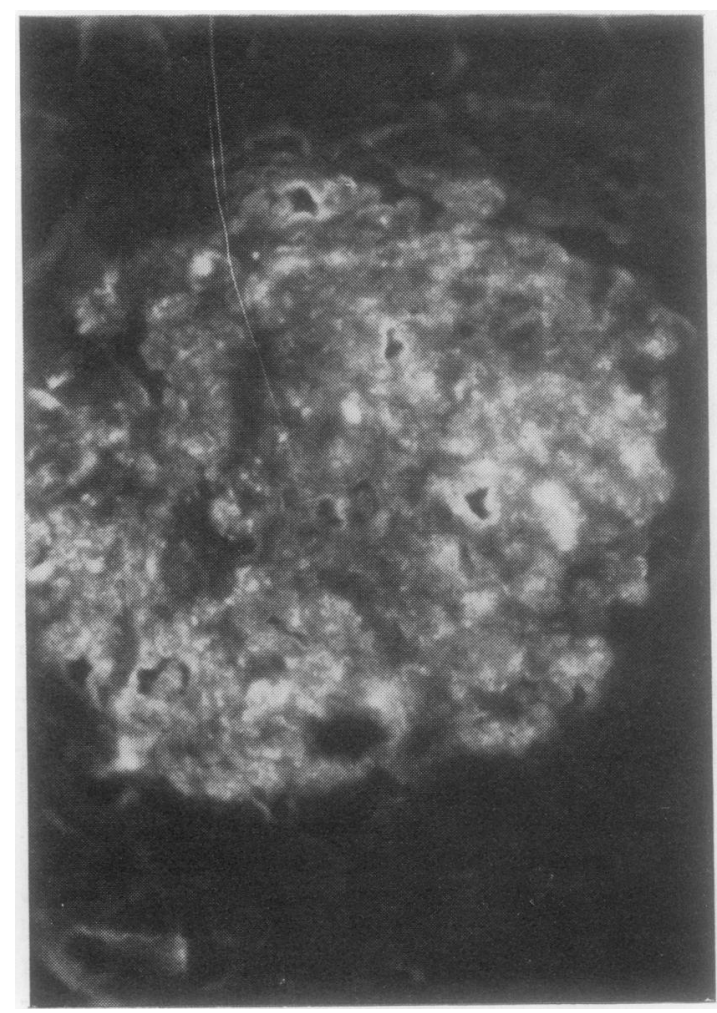

Fig. 2.

Fig. 1 A glomerular tuft partially obliterated by eosinophilous material much of which reacts intensely. Similar deposits of material are present in the wall of the arteriole at the edge of the glomerulus. Note also the capsular fibrosis and the infiltration of the interstitial tissue by lymphocytes and plasma cells (haematoxylin and eosin $\times 350$ ).

Fig. 2 Cryostat section of a glomerulus illustrating a diffuse granular deposition of IgG. Reaction with FITC labelled anti-IgG (Hoechst) dilution 1:8 and photographed by ultraviolet light $(\times 400)$. 


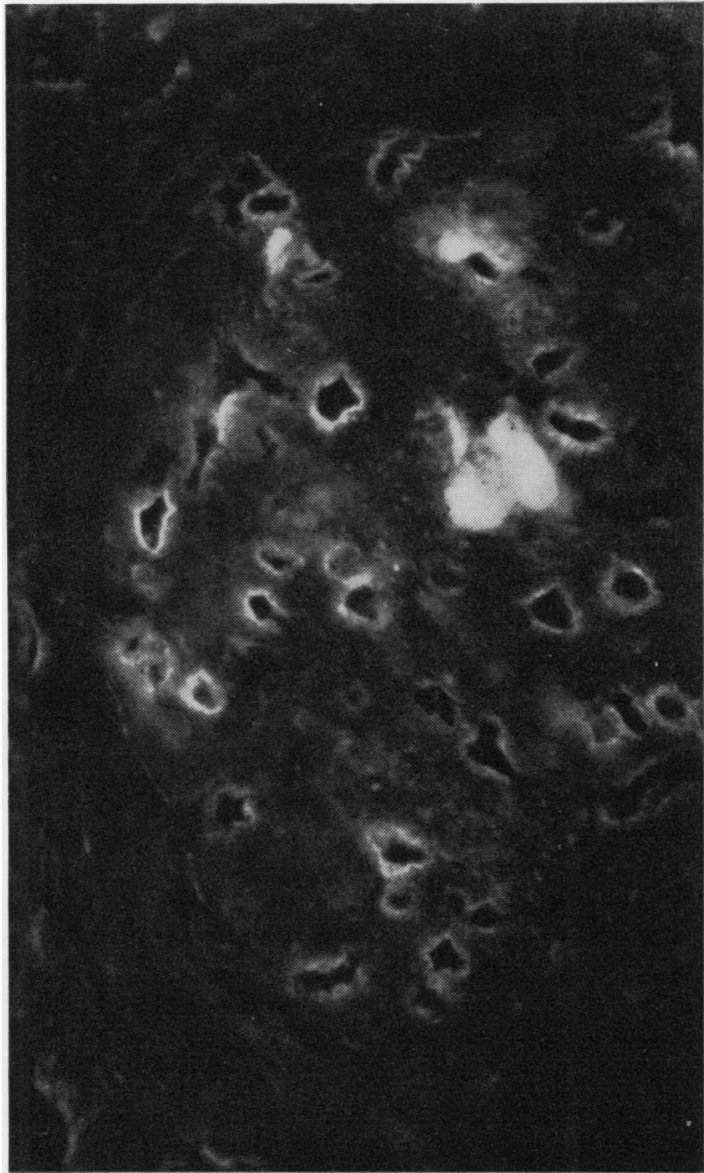

Fig. 3 Cryostat section of a glomerulus demonstrating IgM deposited in the tuft and around what appear to be capillary walls. Reaction with FITC labelled anti-IgM (Hoechst), dilution 1:8 $(\times 800)$.

against a panel of cells of varying $I$ and $i$ antigen strength were as follows:

\begin{tabular}{lll}
\hline Cells & Saline Titre at $4^{\circ} \mathrm{C}$ & $\begin{array}{l}\text { Enzyme Premodified } \\
\text { Cells }\end{array}$ \\
\hline OI & $1: 32$ & $1: 128$ \\
Oi & $1: 4$ & $1: 64$ \\
O cord & $1: 4$ & $1: 32$ \\
Monkey & $1: 32$ & - \\
Rabbit & $1: 128$ & - \\
\hline
\end{tabular}

At $31^{\circ} \mathrm{C}$ in saline there was slight haemolysis but no agglutination against $I$ and $i$ cells. Enzyme premodified cells gave stronger reactions at $37^{\circ} \mathrm{C}$ than at $4^{\circ} \mathrm{C}$ with marked haemolysis in the presence of fresh serum. No Donath Landsteiner activity could be detected. Slight inhibition by $O$ secretor and

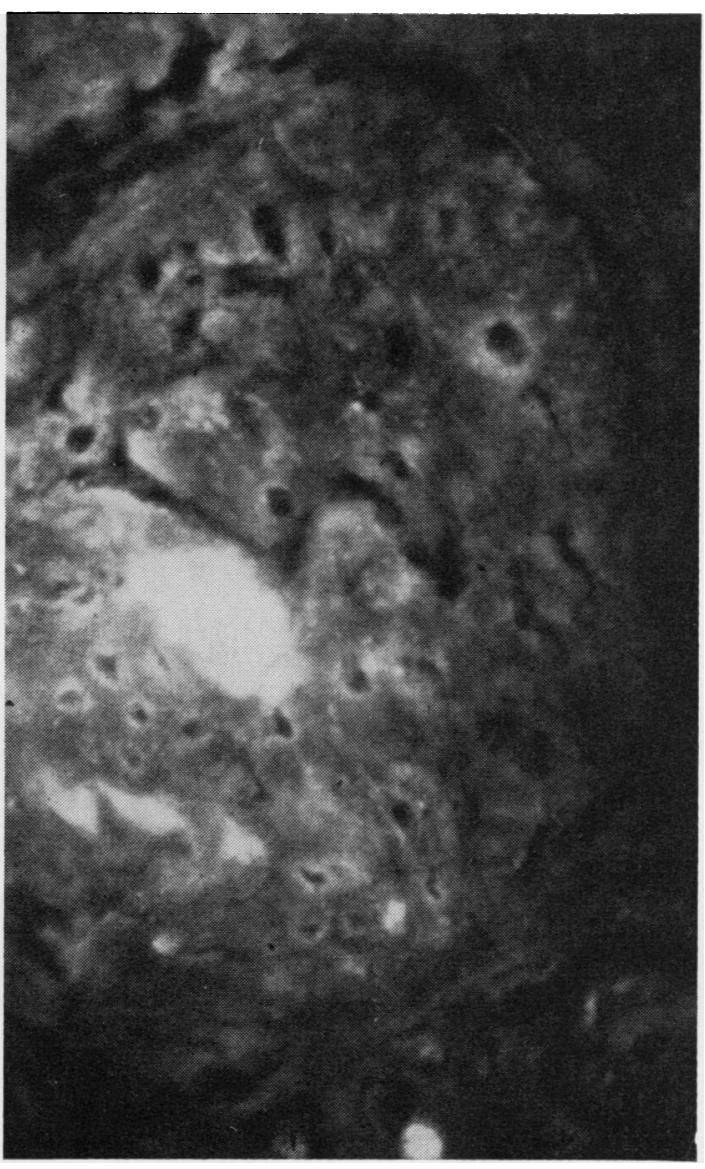

Fig. 4 Cryostat reaction of a glomerulus showing a distribution of beta IC similar to that seen for IgM in Figure 3. Reaction with FITC labelled anti-beta IC (Hoechst $)$ dilution 1:8 $(\times 800)$.

O non-secretor saliva against I cells was noted, but not against $i$ cells. Hydatid cyst fluid had no inhibitory effect. Human milk reduced the titre against I cells by three tubes.

The patient's red cells were coated with complement and an IgM type cold autoantibody with antiI-specificity. Anti-I and anti-i were present in the serum. The serum showed an unusually marked lytic effect for such a low titre of antibody. The anti-I showed no association with $\mathbf{H}$ or $\mathbf{P}$ blood group systems as demonstrated by lack of inhibition by saliva and hydatid cyst fluid.

\section{WHITE CELL SEROLOGY}

In addition to defining antibodies in the patient's serum directed against red cell antigens, a search was 


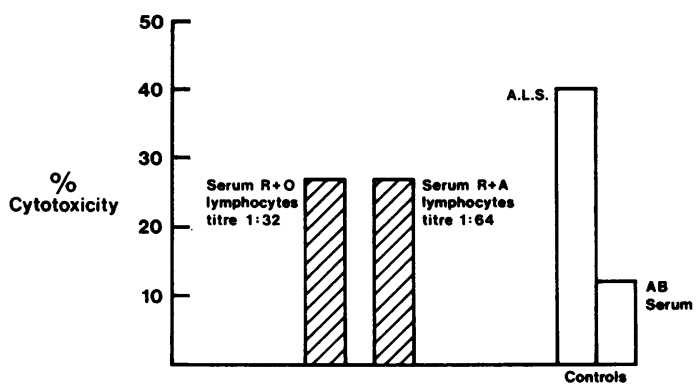

Fig. 5 Maximum cytotoxic activity.

made for serological activity against leucocytes. The method used was a modification of the lymphocytotoxicity test of Rogentine and Plocinik (1967). This measures the ability of specific antibodies to cause the release of isotope from the cytoplasm of human lymphocytes which have been labelled with $\mathrm{Na}_{2}{ }^{51}$ $5 \mathrm{CrO}_{4}$ (sodium chromate) following incubation in the presence of rabbit complement. Initially the test was performed at $37^{\circ} \mathrm{C}$ and also at room temperature $\left(20^{\circ} \mathrm{C}\right)$ under which conditions the patient's serum showed no cytotoxic activity. A cytotoxic effect was clearly shown, however, when the conditions of the test were altered in the following way: serial doubling dilutions of the patient's serum, ${ }^{51} \mathrm{Cr}$-labelled lymphocytes, and rabbit complement were incubated for 18 hours at $4^{\circ} \mathrm{C}$. This was followed by two consecutive periods of incubation of 30 minutes each, first at $20^{\circ} \mathrm{C}$ and then at $37^{\circ} \mathrm{C}$.

The maximum cytotoxic response of the patient's serum was of the order of $25 \%$. This was consistently lower than the value of $40 \%$ found using antilymphocyte serum (ALS) as a positive control (Fig. 5). Titration of the patient's serum gave an endpoint which varied between $1: 32$ and $1: 64$, and this value was found to be independent of the ABO status of the lymphocytes used in the test (Fig. 5).

The patient's serum was absorbed for 18 hours at $4^{\circ} \mathrm{C}$ with group $\mathrm{O}$, leucocyte-poor, washed human adult red cells. Following this absorption the serum titre against papain-premodified group $O$ pooled adult red cells fell from 1:64 to nil. Cytotoxic activity was also measured in this absorbed serum and was found to be markedly less than that of the unabsorbed sample, although it was not possible to define a precise reduction in titre (Fig. 6). Cytotoxicity measurements were not made on eluates of red cells following absorption with the patient's serum.

These findings indicated that the patient's serum contained an antibody which was weakly cytotoxic to allogeneic human lymphocytes. This antibody

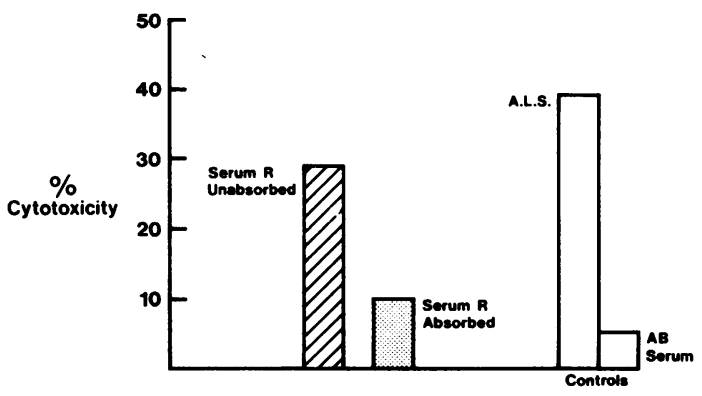

Fig. 6 Cytotoxic activity after absorption with red cells.

required incubation at $4^{\circ} \mathrm{C}$ and then at $37^{\circ} \mathrm{C}$ to manifest its activity in vitro, and this activity was independent of the ABO group of the 'target' lymphocytes. Absorption with group $\mathrm{O}$ adult human red cells appeared to remove most of the cytotoxic activity from the serum.

\section{Discussion}

The case reported here is that of a young Ceylonese man with chronic glomerular nephritis presenting with the nephrotic syndrome and chronic renal failure with normal sized kidneys. The unusual features of the case are the occurrence of cold type autoimmune red cell antibodies, a cold lymphocytotoxic antibody, hypocomplementaemia, and the deposition in the renal glomeruli of eosinophilous material which was not amyloid. Immunofluorescent studies on the specimen of kidney revealed focal glomerular deposits of IgM and beta IC and granular aggregates of IgG and IgA. It is suggested that these immune complexes with or without complement may be causing glomerular injury.

There is some evidence that abnormalities of immunoglobulin synthesis may be incriminated in the pathogenesis of renal disease (Meltzer, Franklin, Elias, McCluskey, and Cooper, 1966; Golde and Epstein, 1968; Morel-Maroger, Basch, Danon, Verroust, and Richet, 1970). Poth, Sharp, and Schrier (1970) suggested a close link between cold agglutinin disease and the nephrotic syndrome in an elderly woman. Unfortunately histological studies on the kidneys were not available.

Many cases of cold type autoimmune haemolytic anaemia due to an antibody of anti-I specificity have ? now been reported. The antibody strength as judged by direct titration is usually high and may be active at $31^{\circ} \mathrm{C}$ when it is then assumed to be capable of causing haemolysis in vivo. In addition it is not uncommon to find anti-i together with anti-I in these 
patients. The serum from the patient reported here contained both anti-I and anti-i and was unusual in its marked lytic effect and low titre. Although in vitro the antibody was active against donor red cells, at $31^{\circ} \mathrm{C}$ no clinical or biochemical evidence of haemolysis was found. The red cell life span was reduced, but this was consistent with the degree of renal functional impairment present.

It is possible that the autoimmune red cell antibodies together with complement could have caused either primary or secondary damage to the renal glomeruli. Whether the $I$ and $i$ antigens occur in human tissues such as the kidney is conjectural. Feizi and Monger (1967) could find no inhibitor of anti-I by kidney homogenates, but Franks (1968) detected both $I$ and $i$ antigens in aneuploid and diploid human cell lines.

The patient's serum was also found to contain a cold antibody which was weakly cytotoxic to allogeneic human lymphocytes under certain conditions in vitro. There is insufficient evidence available to consider the lymphocytotoxic antibody, and those directed against the I red cell antigen system as the same entity.

Considering the findings in the patient and the experimental evidence available it is possible that the glomerular damage resulting in the nephrotic syndrome and progressive renal failure could have been caused by the atypical antibodies in the serum with or without the agency of complement.
We should like to thank Professor de Wardener, Professor J. C. Sloper, and Dr G. D. Pegrum for their encouragement and assistance in publishing the case, also Dr W. J. Jenkins of the North East Metropolitan Regional Blood Transfusion Centre for his detailed analysis of the patient's autoimmune red cell antibody.

Requests for reprints to T.R.M., Haematology Department, Fulham Hospital, St. Dunstan's Road, London, W6.

\section{References}

Feizi, T., and Monger, E. (1967). Search for I antigen in human tissue. Nature (Lond.), 216, 1025-1026.

Franks, D. (1968). Antigens as markers on cultured mammalian cells. Biol. Rev., 43, 17-50.

Golde, D., and Epstein, W. (1968). Mixed cryoglobulins and glomerulonephritis. Ann. intern. Med., 69, 1221-1227.

Lendrum, A. C., Fraser, D. S., Slidders, W., and Henderson, R. (1962). Studies on the character and staining of fibrin. J. clin. Path., 15, $401-413$.

Meltzer, M., Franklin, E. C., Elias, K., McCluskey, R. T., and Cooper, N. (1966). Cryoglobulinaemia-a clinical and laboratory study. II. Cryoglobulins with rheumatoid factor activity. Amer. J. Med., 40, 837-856.

Morel-Maroger, L., Basch, A., Danon, F., Verroust, P., and Richet, G. (1970). Pathology of the kidney in Waldenström's macroglobulinemia. New Engl. J. Med., 283, 123-129.

Poth, J. L., Sharp, G. S., and Schrier, S. L. (1970). Cold agglutinin disease and the nephrotic syndrome. J. Amer. med. Ass., 211, 1989-1992.

Rogentine, G. N., and Plocinik, B. A. (1967). Application of the ${ }^{51} \mathrm{Cr}$ cytotoxicity technique to the analysis of human lymphocyte isoantigens. Transplantation, 5, 1323-1333. 